\title{
THE IMPLEMENTATION EFFECT BLENDED LEARNING APPROACH ON ACCOUNTING KNOWLEDGE AND GENERIC SKILLS
}

\author{
Nurdian Susilowati \\ Lyna Latifah \\ Universitas Negeri Semarang \\ nurdiansusilowati@mail.unnes.ac.id
}

\begin{abstract}
The objectives of the study were; (1) to investigate the influence of blended learning approach implementation towards the accounting knowledge and (2) to investigate the influence of blended learning approach implementation towards the generic skills. It was a quantitative research approach with quasi experimental research design with static group comparison design. The samples of the study were economics education students which were taking the Introduction to Accounting Subject at the materials of adjustment entries. Data were analyzed by descriptive analysis and inferential analysis (independent sample t-test). The results of the study showed that there were differences on students' learning outcomes for the materials of adjustment entries between students who were taught by blended learning approach and those who were taught by conventional method. Moreover; there were also differences on generic skills between those two approaches. Students' generic skills who were taught by blended learning approach were bettter than those who were taught by conventional method.
\end{abstract}

Keywords: blended learning, accounting knowledge, generic skills, accounting education students

Abstrak: Penelitian ini bertujuan untuk mengetahui (1) pengaruh penerapan blended learning approach terhadap pengetahuan akuntansi dan (2) pengaruh penerapan blended learning approach terhadap keterampilan generik. Penelitian ini menggunakan pendekatan penelitian kuantitatif yaitu penelitian quasi eksperimen dengan desain static group comparison dengan sampel mahasiswa pendidikan ekonomi yang sedang mengampu mata kuliah pengantar akuntansi materi jurnal penyesuaian. Metode analisis yang digunakan yaitu analisis deskriptif dan analisis inferensial (independent sample t-test). Hasil penelitian menunjukan bahwa ada perbedaan hasil belajar mahasiswa pada materi jurnal penyesuaian dengan pendekatan blended learning dan metode ceramah. Ada perbedaan keterampilan generik dengan pendekatan blended learning dan metode ceramah. Keterampilan generik mahasiswa yang diajar dengan blended learning lebih baik dibandingkan dengan metode ceramah.

Kata Kunci: blended learning, pengetahuan akuntansi, keterampilan generik, mahasiswa pendidikan akuntansi

Saat ini pendidik di bidang akuntansi mendapat masukan dari profesi akuntan untuk meningkatkan inovasi di dalam desain pembelajaran dan penilaian dalam proses pembelajaran. Hal tersebut diharapkan dapat mengembangkan kedisiplinan dan memberikan fasilitas untuk pengembangan interpersonal yang kuat dan ketrampilan menganalisis untuk menciptakan hasil pembelajaran yang berkelanjutan pada mahasiswa akuntansi. Tantangan untuk meningkatkan pengembangan ketrampilan dan pengetahuan yang tinggi di bidang akuntansi dapat diwujudkan 
dengan menggunakan filosofi pembelajaran yang melibatkan mahasiswa untuk aktif dan integratif di kelas (Biggs, 2003; Ramsden, 2003).

Banyak dosen akuntansi yang mengeluhkan kurangnya waktu dalam penyampaian materi yang disertai dengan latihan. Keterbatasan waktu yang dimiliki di pertemuan tatap muka (faceto-face) dapat disiasati dengan memanfaatkan teknologi komputer di dunia pendidikan. Pembelajaran dengan menggunakan bantuan teknologi seperti e-learning telah banyak diterapkan di perguruan tinggi. Berbagai fasilitas kemudahan belajar mengajar berbantuan teknologi seperti e-learning serta blog untuk dosen disediakan untuk berinteraksi dengan mahasiswa tanpa harus dibatasi oleh waktu.

Adapun penerapan yang dilakukan selain dengan e-learning yaitu dengan blended learning. Blended learning adalah sebuah kemudahan pembelajaran yang menggabungkan berbagai cara penyampaian, model pengajaran, dan gaya pembelajaran, memperkenalkan berbagai pilihan media dialog antara fasilitator dengan individu yang mendapat pengajaran. Menurut Harding, Kaczynski dan Wood (2005) blended learning juga sebagai sebuah kombinasi pengajaran langsung (face-to-face) dan pengajaran online, tapi lebih daripada itu sebagai elemen dari interaksi sosial. Secara terperinci blended learning merupakan pendekatan pembelajaran yang mengintegrasikan pembelajaran tradisonal tatap muka dan pembelajaran jarak jauh yang menggunakan sumber belajar online dan beragam pilihan komunikasi yang dapat digunakan oleh pendidik dan peserta didik.

Teori belajar konstruktivisme memahami hakikat belajar sebagai kegiatan manusia membangun atau menciptakan pengetahuan dengan cara mencoba memberi makna pada pengetahuan sesuai pengalamannya. Pengetahuan itu sendiri rekaan dan bersifat tidak stabil. Oleh karena itu, pemahaman yang diperoleh manusia senantiasa bersifat tentative dan tidak lengkap. Pemahaman manusia akan semakin mendalam dan lengkap. Pemahaman manusia akan semakin mendalam dan kuat jika teruji dengan pengalaman-pengalaman baru. Pandangan Piaget menyatakan bahwa ilmu pengetahuan dibangun dalam pikiran seorang dengan kegiatan asimilasi dan akomodasi sesuai dengan skemata yang dimilikinya. Belajar merupakan proses aktif untuk mengembangkan skemata sehingga pengetahuan terkait bagaikan jaring laba-laba dan bukan sekedar tersusun secara hirarkis.

Dari pengertian di atas, dapat dipahami bahwa pengetahuan diperoleh dari suatu aktivitas yang berlangsung secara interaktif antara faktor intern pada diri pebelajar dengan faktor ekstern atau lingkungan, sehingga melahirkan perubahan tingkah laku. Perubahan tingkah laku yang dimaksud dalam penelitian disini adalah etika dan kesadaran lingkungan. Seseorang mempunyai pengetahuan mengenai lingkungannya yang didapat dari melihat, memahami, informasi pihak 
lain, fenomena, tantangan dan permasalahan di lingkungannya. Dari hal tersebut membentuk menjadi sebuah pengetahuan. Jika dikaitkan dengan pembelajaran, maka hasil belajar merupakan bentuk dari pengetahuan tersebut.

Harwood \& Cohen (1999) mengemukakan bahwa kebutuhan untuk menumbuhkan ketrampilan belajar (termasuk di dalamnya keterampilan generik) seumur hidup pada mahasiswa dengan fokus tidak pada apa yang diajarkan oleh dosen namun menekankan pada bagaimana mahasiswa belajar. Dalam konteks ini, mahasiswa juga mengalami perubahan dalam praktek pembelajaran akuntansi dengan berperan aktif dalam proses pembelajaran. Tujuan dari meningkatkan keaktifan mahasiswa dalam pembelajaran tidak hanya untuk mencapai pendekatan pembelajaran yang lebih dalam namun juga untuk meningkatkan kemampuan komunikasi dan interaksi sosial dalam pembelajaran.

Menurut Kamsah, (2004) keterampilan generik merupakan keterampilan employability yang digunakan untuk menerapkan pengetahuan. Keterampilan ini bukan keterampilan bidang pekerjaan tertentu, namun keterampilan yang melintasi semua bidang pekerjaan pada arah horizontal dan melintasi segala tingkatan mulai dari tingkat pemula hingga manajer eksekutif pada arah vertikal.

Definisi ini senada dengan yang dikemukakan National Skill Task Force (Pumphey dan Slater (2002), bahwa keterampilan generik adalah keterampilan yang melintasi sejumlah pekerjaan yang berbeda. Kearns (dalam Yeung et al., 2007) mendefinisikan keterampilan generik sebagai keterampilan dan atribut-atribut untuk hidup dan bekerja. Lebih lanjut Yeung et al. (2007) menyatakan bahwa keterampilan generik sangat berguna untuk melanjutkan pendidikan dan kesuksesan karir. Berdasarkan pengertian di atas dapat disimpulkan bahwa keterampilan generik merupakan keterampilan yang diperlukan untuk berbagai bidang pekerjaan dan kehidupan. Komunikasi dalam sains tentu saja berbeda dengan komunikasi yang kreatif dalam bahasa, akan tetapi terdapat aspek-aspek komunikasi yang sama. Aspek-aspek yang sama ini merupakan keterampilan generik.

Menurut Pumphey \& Slater (2002), keterampilan generik yang diperlukan untuk berbagai bidang pekerjaan meliputi delapan keterampilan seperti ditunjukkan dalam tabel berikut.

\section{Tabel 1. Keterampilan Generik}

\begin{tabular}{ll}
\hline \multicolumn{1}{c}{ Ketrampilan Generik } & \multicolumn{1}{c}{ Deskripsi } \\
\hline Komunikasi & $\begin{array}{l}\text { Verbal, tertulis, bahasan, komunikasi dengan pelanggan (misalnya penjualan, } \\
\text { pemasaran, menangani hubungan dengan pelanggan), membina hubungan, } \\
\text { komunikasi profesional (misalnya keterampilan mempengaruhi/bernegosiasi) }\end{array}$ \\
\hline $\begin{array}{l}\text { Peningkatan } \\
\text { Pembelajaran dan } \\
\text { Kinerja Diri }\end{array}$ & $\begin{array}{l}\text { Berpikir secara mandiri, mandiri, pengembangan diri, evektifitas personal, } \\
\text { kemauan untuk belajar, profesionalisme }\end{array}$ \\
\hline Teknologi Informasi & Mengetik, computing, keterampilan teknologi informasi (misalnya word \\
\hline
\end{tabular}




\begin{tabular}{ll}
\hline & processing, spreadsheets, menangani data, email, internet) \\
\hline Manajemen & Orang, kinerja, sumber, perubahan, proyek, kontrak, dan manajemen resiko \\
\hline Numerasi & Menerapkan bilangan, menghitung \\
\hline Organisasi Kerja & $\begin{array}{l}\text { Pengadministrasian, perencanaan, berpikir ke depan, penjadwalan, proses kerja } \\
\text { (misalnya alokasi kerja, organisasi, penetapan target, manajemen waktu, efisiensi) }\end{array}$ \\
\hline Pemecahan Masalah & $\begin{array}{l}\text { Inovasi, bertanggungjawab, fleksibilitas, adaptif, kemampuan menangani } \\
\text { perubahan/tekanan, berpikir analitik, penilaian/berpikir kritis, pengambilan } \\
\text { keputusan }\end{array}$ \\
\hline Kerja Sama & $\begin{array}{l}\text { Kemampuan untuk bekerja dengan orang lain, komunikasi horizontal (misalnya } \\
\text { koordinasi), kerja kolaboratif, pemotivasian kerja. }\end{array}$ \\
\hline
\end{tabular}

Berdasarkan paparan di atas, maka penelitian ini dilakukan untuk (1) mengetahui pengaruh penerapan blended learning approach terhadap hasil belajar akuntansi mahasiswa materi jurnal penyesuaian dan (2) mengetahui pengaruh penerapan blended learning approach terhadap keterampilan generik mahasiswa materi jurnal penyesuaian.

\section{METODE}

Penelitian kuantitatif ini menggunakan pendekatan penelitian quasi eksperimen dengan desain static group comparison. Dalam desain tersebut akan dibandingkan antara 2 kelas, kelas pertama menjadi kelas eksperimen dan kelas yang kedua menjadi kelas kontrol. Kedua kelompok tersebut masing-masing akan diberikan pre-test sebelum perkuliahan dimulai untuk melihat kemampuan akademis untuk melihat homogenitas kemampuan intelektual mereka. Kelas eksperimen akan diobservasi perbaikan kemampuan keterampilan generik dan pengetahuan akuntansi di setiap pertemuan, namun pengukuran tingkat penguasaan keterampilan generik dan pengetahuan akuntansi akan dinilai dua kali yaitu pada pertemuan pertama sebelum perkuliahan dimulai dan pada pertemuan ketiga pada saat akhir dari perlakuan.

Populasi penelitian ini adalah semua mahasiswa Jurusan Pendidikan Ekonomi yang sedang mengampu mata kuliah Pengantar Akuntansi materi jurnal penyesuaian. Adapun sampel penelitiannya adalah mahasiswa Pendidikan Akuntansi A sebagai kelas eksperimen dan Pendidikan Akuntansi B sebagai kelas kontrol. Adapun desain penelitian yang digunakan sebagai berikut.

\section{Tabel 2. Nonequivalent Control Group Design}

\begin{tabular}{cccc}
\hline Kelas & Pretest & Treatment & Posttest \\
\hline Eksperimen & $\mathrm{O} 1$ & $\mathrm{X} 1$ & $\mathrm{O} 2$ \\
\hline Kontrol & $\mathrm{O} 3$ & $\mathrm{X} 2$ & $\mathrm{O} 4$ \\
\hline
\end{tabular}

Sumber: Sugiyono $(2008,79)$

Keterangan:

$\mathrm{O} 1$ = pretest kelompok eksperimen

$\mathrm{O} 2$ = posttest $\mathrm{kelompok}$ eksperimen 
$\mathrm{O} 3$ = pretest kelompok kontrol

$\mathrm{O} 4$ = posttest kelompok kontrol

Selanjutnya akan dibandingkan pencapaian generik skill dan pengetahuan akuntansi antara kelas eksperimen dan kelas kontrol dengan menggunakan uji independent sample t-test. Teknik pengumpulan data yang digunakan dalam penelitian ini adalah dengan menggunakan kuesioner. Penyebaran kuesioner untuk pengumpulan data dalam penelitian ini dilakukan secara langsung oleh peneliti. Metode analisis data yang digunakan adalah analisis deskriptif dan uji beda ( $t$-test). Kriteria penerimaan $\mathrm{H}_{0}$ jika sig (2 tailed) lebih dari 0,05 dan ditolak $\mathrm{H}_{0}$ apabila sig (2-tailed) kurang dari 0,05.

\section{HASIL DAN PEMBAHASAN}

Deskripsi data dalam penelitian ini memberikan gambaran mengenai hasil penelitian yang telah dilakukan. Sampel ini terdiri atas dua kelas, yaitu kelas eksperimen (Pendidikan Akuntansi A) dengan jumlah 58 dan kelas kontrol (Pendidikan Akuntansi B) dengan jumlah 57 mahasiswa. Kelas eksperimen adalah kelas yang mendapatkan perlakuan (treatment) dengan menggunakan metode pembelajaran blended learning, sedangkan kelas kontrol adalah kelas yang menggunakan metode pembelajaran ceramah. Deskripsi data dalam penelitian ini juga membahas tentang hasil belajar siswa pada pembelajaran Jurnal Penyesuaian. Deskripsi data yang disajikan dalam penelitian ini meliputi mean (rata - rata), median (skor yang membatasi $50 \%$ di atas dan $50 \%$ di bawah), minimum, dan maximum. Adapun penjelasan secara rinci mengenai deskripsi data tersebut dapat dijelaskan sebagai berikut :

Berdasarkan rekapitulasi nilai pre test kelas kontrol yang diolah dengan bantuan program SPSS pada pilihan Explore, diperoleh nilai pre test kelas eksperimen dengan perolehan mean sebesar 69,8793; minimum sebesar 60,00; dan maximum sebesar 76,00. Mengacu pada rekapitulasi nilai pre test kelas eksperimen, maka dapat divisualisasikan ke dalam histogram mengenai data nilai pre test kelas. Hasil penelitian menunjukkan bahwa siswa kelas kontrol paling banyak meraih nilai antara 60 sampai dengan kurang dari 70, yaitu sebanyak 24 mahasiswa. Untuk siswa yang nilainya $\geq 70$ sebanyak 34 mahasiswa.

Berdasarkan rekapitulasi nilai pre test kelas yang diolah dengan bantuan program SPSS pada pilihan Explore, diperoleh nilai pre test kelas eksperimen dengan perolehan mean sebesar 68,8421; median sebesar 70,00; minimum sebesar 60,00; dan maximum sebesar 76,00. Mengacu pada rekapitulasi nilai pre test kelas eksperimen, maka dapat divisualisasikan ke dalam histogram mengenai data nilai pre test kelas eksperimen. Hasil penelitian menunjukkan bahwa mahasiswa 
kelas eksperimen paling banyak meraih nilai antara 60 sampai dengan kurang dari 70, yaitu sebanyak 28 siswa. Untuk mahasiswa yang nilainya $\geq 70$ sebanyak 29 siswa.

Berdasarkan deskripsi data nilai pre test kelas eksperimen dan kelas kontrol, dilakukan uji beda dua pihak terhadap kedua kelas tersebut. Uji ini dilakukan dengan bantuan program SPSS pada pilihan Paired Sample T Test dengan hasil thitung = 0,268, kemudian hasil thitung tersebut dibandingkan dengan 0,05 . Setelah dibandingkan ternyata nilai thitung lebih besar dari 0,05 $(0,268>0,05)$, maka dapat dinyatakan tidak terdapat perbedaan secara signifikan terhadap nilai pre test kelas eksperimen dengan nilai pre test kelas kontrol sebelum diberi perlakuan, sehingga penelitian dapat dilakukan dengan memberikan perlakuan (treatment) pada tiap kelompok kelas. Data hasil uji beda dua pihak pre test kelas eksperimen dengan pre test kelas kontrol selengkapnya dapat dilihat padalampiran halaman 79.

Berdasarkan rekapitulasi nilai post test kelas kontrol yang diolah dengan bantuan program SPSS pada pilihan Explore, diperoleh nilai post test kelas kontrol dengan perolehan mean sebesar 75,3276. Hasil penelitian menunjukkan bahwa siswa kelas kontrol paling banyak meraih nilai antara 65 sampai dengan kurang dari 75, yaitu sebanyak 26 mahasiswa. Untuk siswa yang lulus KKM nilainya $\geq 70$ sebanyak 32 mahasiswa. Berdasarkan rekapitulasi nilai post test kelas eksperimen (lihat lampiran halaman 81) yang diolah dengan bantuan program SPSS pada pilihan Explore, diperoleh nilai post test kelas eksperimen dengan perolehan mean sebesar 89,0351; median sebesar 90,00; minimum sebesar 80,00; dan maximum sebesar 96,00. Hasil penelitian menunjukkan bahwa siswa kelas eksperimen paling banyak meraih nilai antara 80 sampai dengan kurang atau sama dengan 90, yaitu sebanyak 44 mahasiswa. Untuk siswa nilainya $>90$ sebanyak 13 mahasiswa.

Berdasarkan uraian - uraian deskripsi data nilai pre test - post test kelas eksperimen dan deskripsi data nilai pre test - post test kelas kontrol, guna untuk mengetahui apakah hasil belajar kedua kelas tersebut terdapat peningkatan terhadap pengaruh perlakuan, maka dilakukan perbandingan antara keduanya. Untuk mempermudah membandingkan hasil belajar pre test post test antara kelas eksperimen dengan kelas kontrol, maka berikut ini disajikan ke dalam bentuk tabel perbandingan yang berupa rata - rata antara kelas eksperimen dan kelas kontrol sebagai berikut.

Tabel 3. Perbandingan Peningkatan Hasil Belajar Antara Kelas Eksperimen dengan Kelas Kontrol

\begin{tabular}{lcccc}
\hline \multicolumn{1}{c}{ Kelas } & $\begin{array}{c}\text { Nilai Rata-rata } \\
\text { kelas pre test }\end{array}$ & $\begin{array}{c}\text { Nilai Rata-rata } \\
\text { kelas post test }\end{array}$ & Peningkatan & Presentase kenaikan \\
\hline Kontrol & 69,8793 & 75,3276 & 5,4483 & $7,79673 \%$ \\
\hline Eksperiment & 68,8421 & 89,0351 & 20,193 & $29,33 \%$ \\
\hline
\end{tabular}


Berdasarkan tabel perbandingan peningkatan hasil belajar di atas, dapat disimpulkan bahwa hasil belajar siswa kelas eksperimen yang diajar menggunakan metode pembelajaran blended learning lebih tinggi daripada hasil belajar kelas kontrol yang diajar menggunakan metode pembelajaran ceramah. Hal tersebut dibuktikan dengan adanya perbandingan peningkatan hasil belajar, yaitu hasil belajar kelas eksperimen lebih tinggi dibandingkan dengan hasil belajar kelas kontrol $(5,4483>20,193)$.

Pengaruh penerapan metode pembelajaran blended learning terhadap hasil belajar materi jurnal penyesuaian mahasiswa sebagai berikut.

Tabel 4. Rangkuman Data Kelas Eksperimen dan Kelas Kontrol

\begin{tabular}{llllll}
\hline No & \multicolumn{1}{c}{ Keterangan } & \multicolumn{1}{c}{ Kelas } & Kriteria & Uji t & Perbedaan \\
\hline 1. & Pre test & Eksperimen & 69,8793 & 0,268 & Tidak signifikan \\
\hline & & Kontrol & 68,8421 & & \\
\hline 2. & Post test & Eksperimen & 75,3276 & 0,000 & signifikan \\
\hline & & Kontrol & 89,0351 & & \\
\hline
\end{tabular}

Mengacu pada tabel rangkuman data di atas, terlihat bahwa perolehan rata - rata pre test kelas eksperimen hampir sama dengan kelas kontrol, sedangkan perolehan rata - rata post test kelas eksperimen lebih tinggi dibandingkan dengan kelas kontrol. Untuk mengetahui perbandingan hasil belajar kelas eksperimen lebih tinggi atau lebih rendah dari hasil belajar kelas kontrol maka dilakukan uji t. Hasil uji t dari pre test adalah 0,268 $(0,268>0,05)$, maka dapat dinyatakan bahwa tidak terdapat perbedaan secara signifikan sebelum pemberian perlakuan, sedangkan hasil uji t dari post test adalah $0,000(0,000<0,05)$, maka dapat dinyatakan bahwa terdapat perbedaan secara signifikan setelah pemberian perlakuan dan hipotesis diterima. Dengan demikian dapat dinyatakan bahwa kelas eksperimen mendapatkan hasil yang berbeda dengan kelas kontrol.

Kelas eksperimen dari hasil analisis deskriptif mengenai prestasi belajar akuntansi yang lebih baik dari kelas eksperimen disebabkan karena mereka memiliki kesempatan untuk berlatih soal yang lebih banyak dibandingkan dengan kelas kontrol. Hal ini sejalan dengan penelitian yang dilakukan oleh Izzudin Syarif, Hasil penelitian menunjukkan ada perbedaan yang signifikan antara motivasi dan prestasi belajar siswa yang menggunakan model blended learning dan siswa yang menggunakan model face-to-face learning, ada peningkatan motivasi dan prestasi belajar siswa yang signifikan akibat penerapan model blended learning, dan tidak terdapat interaksi pengaruh penerapan model pembelajaran dan motivasi terhadap prestasi belajar siswa.

Pembelajaran dengan model blended learning mampu menggeser prinsip pembelajaran dari teacher center menuju student center secara dinamis. Pembelajaran model blended learning bersifat saling melengkapi kekurang pembelajaran model face to face learning dan e-learning, 
sebab menurut Munir (2009: 176) kelemahan pembelajaran eelearning diantaranya mahasiswa dan guru terpisah secara fisik sehingga interaksi secara tatap muka menjadi berkurang. Selain itu e-elearning cenderung pada pelatihan daripada pendidikan yang mengarah pada kemampuan kognitif dan psikomotirk dan kurang memperhatikan aspek afektif. Lewat face to face learning guru mampu memfungsikan dirinya sebagai pendidik dan memberikan dorongan motivasi secara langsung dan ekspresif pada siswa. Model blended learning membuat aktifitas mahasiswa dalam kelas menjadi lebih variatif. Mahasiswa tidak hanya bertumpu pada informasi yang disampaikan oleh guru.

Pengelolaan pembelajaran oleh dosen dengan mengimplementasikan metode blended learning selama kegiatan pembelajaran berlangsung yang diamati dengan pedoman observasi, hasilnya dapat dilihat pada tabel berikut ini:

Kriteria pengamatan diberikan nilai 1-4

$$
\begin{aligned}
& 1=\text { Kurang } \\
& 2=\text { Cukup } \\
& 3=\text { Baik } \\
& 4=\text { Sangat Baik }
\end{aligned}
$$

\begin{tabular}{clcc}
\hline No & \multicolumn{1}{c}{ Variabel yang diamati } & Kelas kontrol & Kelas eksperimen \\
\hline 1. & Penggunaan bahasa oleh dosen & 3 & 3 \\
\hline 2. & Suasana belajar & 3 & 4 \\
\hline 3. & Variasi penggunaan sumber belajar & 3 & 4 \\
\hline 4. & Ketepatan penggunaan media & 3 & 3 \\
\hline 5. & Ketepatan penggunaan metode & 3 & 3 \\
\hline 6. & Penghargaan terhadap siswa & 3 & 4 \\
\hline 7. & Ketepatan evaluasi & 3 & 4 \\
\hline
\end{tabular}

\begin{tabular}{|c|c|c|c|c|}
\hline No & Ketrampilan & Aspek yang diamati & $\begin{array}{c}\text { Kelas } \\
\text { kontrol }\end{array}$ & $\begin{array}{c}\text { Kelas } \\
\text { eksperimen }\end{array}$ \\
\hline 1. & Komunikasi & $\begin{array}{l}\text { Verbal, tertulis, bahasan,, komunikasi dengan } \\
\text { pelanggan (misalnya penjualan, pemasaran, } \\
\text { menangani hubungan dengan pelanggan), membina } \\
\text { hubungan, komunikasi profesional (misalnya } \\
\text { keterampilan mempengaruhi/ bernegosiasi) }\end{array}$ & 3 & 3 \\
\hline 2. & $\begin{array}{l}\text { Peningkatan } \\
\text { Pembelajaran dan } \\
\text { Kinerja Diri }\end{array}$ & $\begin{array}{l}\text { Berpikir secara mandiri, mandiri, pengembangan } \\
\text { diri, evektifitas personal, kemauan untuk belajar, } \\
\text { profesionalisme }\end{array}$ & 3 & 4 \\
\hline 3. & Teknologi Informasi & $\begin{array}{l}\text { Mengetik, computing, keterampilan teknologi } \\
\text { informasi (misalnya word processing, spreadsheets, } \\
\text { menangani data, email, internet) }\end{array}$ & 3 & 4 \\
\hline 4. & Manajemen & $\begin{array}{l}\text { Orang, kinerja, sumber, perubahan, proyek, } \\
\text { kontrak, dan manajemen resiko }\end{array}$ & 3 & 3 \\
\hline 5. & Numerasi & Menerapkan bilangan, menghitung & 3 & 4 \\
\hline
\end{tabular}

Dari tabel diatas menunjukkan ketrampilan dosen dalam pengelolaan pembelajaran dengan rentangan penilaian 1-4 pada kategori baik (rerata dari semua aspek yang diamati, sedangkan mengenai generik skill dalam proses pembelajaran dapat dilihat dari data berikut ini: 


\begin{tabular}{lllll}
\hline 6. Organisasi Kerja & $\begin{array}{l}\text { Pengadministrasian, perencanaan, berpikir ke } \\
\text { depan, penjadwalan, proses kerja (misalnya alokasi } \\
\text { kerja, organisasi, penetapan target, manajemen } \\
\text { waktu, efisiensi) }\end{array}$ & 3 & 4 \\
\hline 7. Pemecahan Masalah & $\begin{array}{l}\text { Inovasi, bertanggungjawab, fleksibilitas, adaptif, } \\
\text { kemampuan menangani perubahan/tekanan, } \\
\text { berpikir analitik, penilaian/ berpikir kritis, } \\
\text { pengambilan keputusan }\end{array}$ & 4 \\
\hline 8. Kerja Sama & $\begin{array}{l}\text { Kemampuan untuk bekerja dengan orang lain, } \\
\text { komunikasi horizontal (misalnya koordinasi), kerja } \\
\text { kolaboratif, pemotivasian kerja. }\end{array}$ & 3 \\
\hline
\end{tabular}

Dilihat dari berbagai ketrampilan dalam generik skill, dengan pembelajaran blended learning akan lebih baik dalam peningkatan pembelajaran, penguasaan TIK, numerasi, organisasi kerja,pemecahan masalah dan kerja sama. Pembelajaran blended learning merangsang mahasiswa untuk belajar secara mandiri, dengan melalui media sosial yang digunakan baik facebook dan blog. Dosen memberikan materi dan juga soal latihan yang harus dikerjakan secara berkelompok melalui media sosial, kemudian hasil tersebut juga akan dikirimkan melalui e-mail.

Dengan demikian, waktu yang sangat terbatas dikelas, dapat diatasi dengan interaksi antara dosen dan mahasiswa lewat dunia maya. Pengerjaan soal secara berkelompok akan meningkatkan kemampuan mahasiswa dalam komunikasi dan kerjasama tim. Latihan yang diberikan juga dapat meningkatkan kemampuan mengerjakan soal hitungan yang berbentuk numerik. Interaksi antara dosen dan mahasiswa diluar kelas dengan melalui sosial media juga meningkatkan kemampuan mahasiswa dalam Teknilogi dan Ilmu Komunikasi. Keterampilan generik yang dikaitkan dengan pendidikan universitas melingkupi keterampilan tingkat tinggi dalam hal komunikasi tertulis, komunikasi lisan, berpikir kritis dan analitis, pemecahan masalah, bekerjasama, belajar mandiri, melek informasi, keterampilan interpersonal, serta etika dan nilainilai. Oleh karena keterampilan generik relatif bebas dari disiplin ilmu, maka keterampilanketerampilan ini seharusnya juga dimiliki oleh lulusan universitas.

\section{SIMPULAN}

Hasil penelitian ini menunjukan bahwa (1) ada perbedaan hasil belajar kelas kontrol dengan kelas eksperimen pada materi jurnal penyesuaan perusahaan dagang yang artinya ada pengaruh penerapan blended learning approach terhadap hasil belajar mahasiswa dan (2) ada perbedaan keterampilan generik kelas kontrol dengan kelas eksperimen pada materi jurnal penyesuaan perusahaan dagang yang artinya ketrampilan generik mahasiswa dengan pembelajaran blended learning lebih baik daripada siswa yang diajar dengan metode pembelajaran ceramah. Pembelajaran dengan model blended learning mampu menggeser prinsip pembelajaran dari teacher center menuju student center secara dinamis. Pembelajaran model 
blended learning bersifat saling melengkapi kekurang pembelajaran model face to face learning dan e-learning, sebab menurut Munir (2009: 176) kelemahan pembelajaran eelearning diantaranya mahasiswa dan guru terpisah secara fisik sehingga interaksi secara tatap muka menjadi berkurang

Sehubungan dengan hasil penelitian dan pembahasan, untuk mencapai hasil belajar dengan penerapan metode pembelajaran yang sesuai dengan yang diharapkan, maka disarankan (1) dosen dapat menerapkan metode pembelajaran sesuai dengan karakter kelas, (2) dosen dapat memberikan stimulus agar kelas dapat aktif, dan (3) implementasi blended learning dengan menggunakan macam variasinya.

\section{DAFTAR PUSTAKA}

Barroso, J. \& Cabranes, G. (2009). Face to face learning methodologies vs distance mearning methodologies: case study online using qualitative analysis. International Conference of Multimedia and ICT in Education.

Bersin, J. (2004). The Blended Bearning Book:Best Bractices, Proven Methodologies, and Lessons Learned. San Francisco: Pfeiffer.

Biggs, J. (2003). Teaching for Quality Learning at University. Great Britain: Open University Press.

Cottell, P. G. Jr., \& Millis, B. J. (1992). Cooperative Learning in Accounting. Journal of Accounting Education, 10, pp. 95-111.

Purwaningsih, D. \& Pujianto. (2009). blended cooperative e-learning (bcel) sebagai sarana pendidikan penunjang learning community. Disampaikan dalam Seminar Nasional UNY dengan tema "Peranan ICT (Information and Communication Technology) dalam Pembelajaran" pada tanggal 25 Juli 2009 di Ruang Sidang Utama Rektorat UNY.

Fatimah,S., Kartika, I., \& Niyartama, T. F. Pembelajaran fisika menggunakan model cooperative learning ditinjau dari prestasi belajar siswa. Jurnal Kependidikan, 42 (1), pp. 1-6.

Harwood, E. M. \& Cohen, J. R. (1999). Classroom assessment: Educational and research opportunities. Issues in Accounting Education, 14 (4), pp. 691-724.

Johnson, D. \& Johnson, R. (1994). Learning together and alone, cooperative, competitive, and individualistic learning. Needham Heights, MA: Prentice-Hall.

Kamsah, M.Z. (2004). Developing Generic Skills in Classroom Environment: Engineering Student's Perspective.

Kuswandi, D. (2001). Validasi Media: Analisis Kelayakan Media yang Akan Dikembangkan. Bahan Kuliah tidak diterbitkan. Malang: Jurusan TEP FIP UM.

Peek, L. E., Winking, C., \& Peek, G. S. (1995). Cooperative learning activities: Managerial accounting. Issues in Accounting Education (Spring): 111-125.

Procter,C. (2003). Blended Learning ini Practice. Disajikan pada Education ini A Changing Environment, Manchester, UK, 17-18 Septermber 2003. University of Salford, (online), http://www. Edu.salford.ac.uk diakses 5 Februari 2012.

Puslitjaknov. 2008. Metode Penelitian Pengembangan. Jakarta: Departemen Pendidikan Nasional.

Pumphrey, J. \& Slater, J. (2002). An Assessment of Generic Skill Needs. Notingham: Department for Education and Skills.

Ramsden, P. (2003). Learning to Teach in Higher Education. London: RoutledgeFalmer. Sanjaya, W. (2006). Strategi Pembelajaran. Jakarta: Media Prenada. 
Setiyosari, P. (2010). Metode Peneliltian Pendidikan dan Pengembangan. Jakarta: Kencana Prenada Media Group.

Sloman, M. (2007). Making Sense of Blended Learning. Industrial and Commercial Training, 39 (6), 315-318, (online), http://emeraldinsight.com, diakses 7 Februari 2012.

Stacey, E. \& Gerbic, P. (2009). Effective Blended Learning Practices : Evidence-based Perspectives in ICT-Facilitated Education. Newyork: Hersey.

Sugiyono. (2008). Metode Penelitian Kuantitatif Kualitatif dan R\&D. Bandung: Alfabeta.

Suharsimi. (2003). Dasar-dasar Evaluasi Pendidikan, Edisi Revisi, Cet. ke-6. Jakarta: Bumi Aksara.

Sullivan, E. J. (1996). Teaching financial statement analysis: A cooperative learning approach. Journal of Accounting Education, 14 (1), pp. 107-111.

Suwastono, A. (2011). Pengembangan E-Learning berbasis moodele pada mata kuliah penginderaan jauh S-1 Jurusan Geografi Universitas Negeri Malang. Tesis.

Thorne, K. (2003). Blended Learning : How to integrate online and Traditional Learning. London: Kogan Page Limited.

Wilson, D. \& Smilanicth, E. (2005). The Other Blended Learning: A Classroom-Centered Approach. San Francisco: Pfeiffer. 